The cable, roughly crossing the auroral zone perpendicularly, may be expected to have a minimum of interruptions on account of earth-current storms. The initial outlay for the proposed cable would be greater than that for a simple transatlantic cable between Europe and the east coast of North America; nevertheless, it would be cheaper than two independent cables from Thule to (a) the U.S., and (b) Europe. The actual laying of transarctic cables, although rather more difficult, is not impossible in an age where nuclearpowered icebreakers and submarines are available.

The Arctic is becoming increasingly accessible. Transpolar flights are rou- tine. On a long-term basis there is little doubt that as civilization advances northward, additional communication circuits will be needed from middle latitudes of North America and Europe to the Arctic. In addition, more circuits will be required for intra-arctic use.

One final word may be said about arctic communications: all present long-range circuits may be replaced by satellite communication links if a sufficient number of communications satellites having polar orbits become available.

N. C. Gerson*

*Vice Chairman, Arctic Committee, U.S. National Committee for the IGY. Washington, D.C., U.S.A.

\section{BRYOZOA FROM THE ARCTIC ALASKAN COAST}

During a cruise in August 1953 the U.S. Coast and Geodetic Survey LCM Red travelled along the northern Alaskan coast from Barter Island to Barrow. On this occasion a scientific party, in cluding the ichthyologists $N$. J. Wilimovsky and $\mathrm{H}$. Adair Fehlman, and the marine invertebrate zoologist Charles Horvath, was able to occupy a number of hydrographic and collecting stations.

The collections made on this cruise contain the first bryozoan material from the eastern arctic region of Alaska to reach the hands of scientists, except the one sample, containing Eucratea loricata and Hippothoa hyalina, taken by the Canadian Arctic Expedition 1913-18 in this area ${ }^{1}$. The collections are now at the Allan Hancock Foundation at the University of Southern California. Collections of two previous expeditions have been lost: the Investigator from which McClure collected in 1850-3, had to be abandoned; Stefansson had sampled in the area in 1913-14 during the Canadian Arctic Expedition, but the collections were lost with the Karluk.

The Bryozoa reported on here are parts of the samples taken with a small biological dredge at 15 stations listed in Table 1 (from ref. 2). Stations 1, 9, and 14 were shore stations and have therefore been omitted. The following details are added to the original information given in Table 1: gravel was present in the samples from stations $3,4,5,6,11$, $12,15,17$, and 18; clay was found at station 3; kelp (laminarioids) to which bryozoans attach were represented by fragments only in six stations ${ }^{3}$.

In 12 stations 11 species of bryozoans were found. They have all been reported earlier from arctic Alaskan waters, specifically from the Point Barrow area ${ }^{4,5,6}$, and most are common forms. This report establishes the presence of these species eastward beyond Point Barrow. Hippothoa hyalina, Lichenopora canaliculata, Alcyonidium disciforme, and Vesicularia fasciculata were reported for the first time off Point Barrow only in the last decade.

The distribution of the species varied considerably (Table 2). Samples rich in species were taken at stations 7 and 8 . The species with the largest number of individuals and most widely distributed are Alcyonidium disciforme (9) and $E u$ cratea loricata (7). One species is endemic (Vesicularia fasciculata), one is bipolar (Lichenopora canaliculata), and 
Table 1. List of stations.

\begin{tabular}{|c|c|c|c|c|c|c|c|c|c|c|}
\hline $\begin{array}{l}\text { Sta- } \\
\text { tion }\end{array}$ & Locality & Long. & $W$ & Lat. & $N$. & $\begin{array}{l}\text { Date } \\
1953 \\
\text { Aug. }\end{array}$ & $\begin{array}{c}\text { Depth } \\
m .^{*}\end{array}$ & $\begin{array}{l}\text { Sediment } \\
\text { type }\end{array}$ & Kelp & $\begin{array}{l}\text { Bryo- } \\
\text { zoa }\end{array}$ \\
\hline 2 & N. of Arey Island & $143^{\circ}$ & $54^{\prime}$ & $70^{\circ}$ & $08^{\prime}$ & 9 & 10.70 & sand & & \\
\hline 3 & Off Kangigivik Point & $145^{\circ}$ & $14^{\prime}$ & $70^{\circ}$ & $03^{\prime}$ & 9 & 7.30 & sand & + & + \\
\hline 4 & Off Brownlow Point & $145^{\circ}$ & $55^{\prime}$ & $70^{\circ}$ & $12^{\prime}$ & 10 & 12.80 & ? sand & & + \\
\hline 5 & W. of Flaxman Island & $146^{\circ}$ & $15^{\prime}$ & $70^{\circ}$ & $11^{\prime}$ & 10 & 22.80 & sand and mud & + & + \\
\hline 6 & S.E. Stockton Islands & $146^{\circ}$ & $50^{\prime}$ & $70^{\circ}$ & $15^{\prime}$ & 10 & 4.60 & sand and mud & + & + \\
\hline 7 & S. of Cross Island & $147^{\circ}$ & $55^{\prime}$ & $70^{\circ}$ & $26^{\prime}$ & 10 & $\begin{array}{l}7.30- \\
8.25\end{array}$ & gravel & + & + \\
\hline 8 & N. of Long Island & $148^{\circ}$ & $50^{\prime}$ & $70^{\circ}$ & $31^{\prime}$ & 10 & 12.80 & muddy clay & + & + \\
\hline 10 & Off Thetis Island & $150^{\circ}$ & $15^{\prime}$ & $70^{\circ}$ & $34^{\prime}$ & 11 & 7.30 & sand, clay & & \\
\hline 11 & East Harrison Bay & $150^{\circ}$ & $59^{\prime}$ & $70^{\circ}$ & $43^{\prime}$ & 11 & 8.25 & clay, sand & + & + \\
\hline 12 & Off Atigaru Point & $151^{\circ}$ & $50^{\prime}$ & $70^{\circ}$ & $40^{\prime}$ & 11 & 4.60 & sand & & + \\
\hline 13 & $15 \mathrm{mi}$. E. of Pitt Point & $152^{\circ}$ & $25^{\prime}$ & $70^{\circ}$ & $53^{\prime}$ & 11 & 6.40 & clay & & \\
\hline 15 & N.W. of Pitt Point & $153^{\circ}$ & $15^{\prime}$ & $70^{\circ}$ & $57^{\prime}$ & 12 & 7.30 & mud & & + \\
\hline 16 & Smith Bay & $154^{\circ}$ & $16^{\prime}$ & $70^{\circ}$ & $57^{\prime}$ & 12 & 6.10 & sandy clay & & + \\
\hline 17 & $\begin{array}{l}\text { Sanigaruak Pass, } \\
\text { Elson Lagoon }\end{array}$ & $155^{\circ}$ & $24^{\prime}$ & $71^{\circ}$ & $11^{\prime}$ & 12 & $\begin{array}{l}3.65 \\
6.40\end{array}$ & clay & & + \\
\hline 18 & $\begin{array}{l}\text { Elson Lagoon, S.W. } \\
\text { of Cooper Island }\end{array}$ & $155^{\circ}$ & $48^{\prime}$ & $71^{\circ}$ & $13^{\prime}$ & 12 & 3.65 & sand, clay & & + \\
\hline
\end{tabular}

* Originally in feet.

one is cosmopolitan (Hippothoa hyalina). The remaining eight are restricted to the temperate, cool, and cold waters of the northern hemisphere. The identi- several colonies on stones; sta. 18: numerous, on gravel. Circumpolar, northern hemisphere; Point Barrow. Common.

Table 2. The species of Bryozoa in the stations of the LCM Red, 1953.

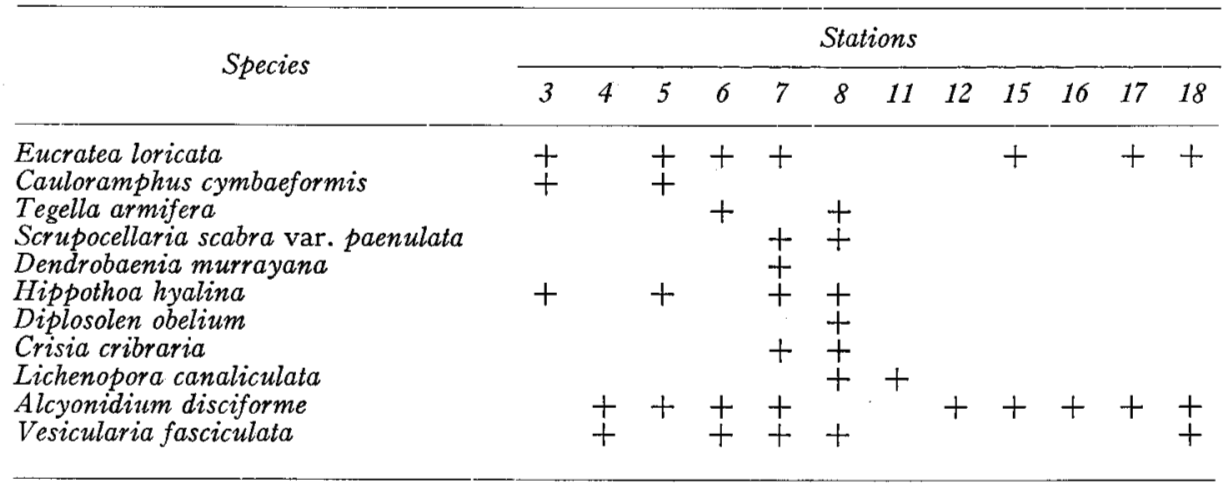

fications of the species are based mainly on ref. 5 .

In the following annotated list of the species their general distribution has been added (after ref. 5,7 , and 8 ).

Eucratea loricata (L.), 1758 - Scrupariidae. Stations 3, 5, 6, 7, 15, 17, 18. Sta. 7: 5 colonies on gravel; sta. 17:
Cauloramphus cymbaeformis (Hincks), 1877-Hincksiniidae. Stations 3, 5. Sta. 3: 1 juv. specimen on alga; sta. 5: 3 colonies on hydroid stems. Circumpolar; Point Barrow. Common.

Tegella armifera (Hincks), 1880 Alderinidae. Stations 6, 8. Sta. 8: 2 
colonies on algae. Circumpolar; circumboreal; Point Barrow.

Scrupocellaria scabra var. paenulata Norman, 1903 - Scrupocellariidae. Stations 7, 8. Sta. 7: 2 colonies, one on gravel, one on alga; sta. 8: several colonies. Circumpolar; Point Barrow. Common.

Dendrobaenia murrayana (Johnston), 1847 - Bicellariellidae. Station 7. One colony on alga. Widely distributed in northern seas; abundant at Point Barrow.

Hippothoa hyalina (L.), 1758 - Hippothoidae. Stations 3, 5, 7, 8. Sta. 3: 5 colonies with ovicells, on algae; 9 colonies without ovicells; sta. 5: 1 colony on hydroid stem; sta. 7: 3 colonies on algae; sta. 8: 2 colonies on algae. Cosmopolitan; Arctic to the tropics; Point Barrow.

Diplosolen obelium (Johnston), 1838 - Diastoporidae. Station 8. One colony on alga. North Atlantic, North Pacific, Chukchi Sea; Point Barrow. Common in Alaskan waters.

Crisia cribraria Stimpson, 1853 Crisiidae. Stations 7, 8. In both stations several colonies on algae. East coast of North America, fairly common; Point Barrow.

Lichenopora canaliculata (Busk), 1876 - Lichenoporidae. Stations 8, 11. In each station 1 colony on alga. Antarctic and far southern waters; several colonies at Point Barrow.

Alcyonidium disciforme (Smitt), 1871 - Alcyonidiidae. Stations 4, 5, 6, 7, 12 , 15, 16, 17, 18. Most frequent species; occurs in great numbers. Sta. 4: 1 colony; sta. 5 : 1 ; sta. 6 : 125 ; sta. 7 : 1 ; sta. 12: 1 ; sta. 15 : 9 ; sta. 16 : 72 ; sta. 17 : 11 ; sta. 18: 39 colonies. Outer diameter 5-45 mm. Circumpolar; Point Barrow.
Vesicularia fasciculata Soule, 1953 Vesiculariidae. Stations 4, 6, 7, 8, 18. Sta. 4: 1 colony; sta. 6: numerous, on gravel; sta. 7: 2 colonies on gravel; sta. 8: 6 colonies; sta. 18: numerous on gravel. Point Barrow.

I am very grateful to Dr. J. L. Mohr for the opportunity to carry out this study. It was aided by a contract between the National Science Foundation and the University of Southern California (G 9612). The use of the laboratory facilities of the Allan Hancock Foundation is also gratefully acknowledged.

\section{Kunigunde Hulsemann *} JohN D. SOULE†

*Department of Biology, University of Southern California.

†School of Dentistry and Allan Hancock Foundation, University of Southern California.

1CAE station 27s, Collinson Point, Camden Bay, $70^{\circ} 24^{\prime} \mathrm{N}$. $161^{\circ} 25^{\prime} \mathrm{W}$., Oct. $3 / 4,1913$, 3 fathoms.

${ }^{2}$ Wilimovsky, N.J. 1953. Cruise of the Coast and Geodetic Survey LCM RED. Stanford Univ., Nat. Hist. Mus. Contract N 6onr25136 Nr. 307204. Tech. Rept. III, 3 pp.

${ }^{3}$ Mohr, J. L., N. J. Wilimovsky, and E. Y. Dawson. 1957. An arctic Alaskan kelp bed. Arctic 10:45-52.

${ }^{4}$ Osburn, R. C. 1923. Bryozoa. Canadian Arctic Expedition 1913-18, 8, Pt. D, 13 pp.

5 -1950-3. Bryozoa of the Pacific coast of America. Allan Hancock Pacific Expedition. 14, in 3 pts. (Suborder Ctenostomata in pt. 3 by R. C. Osburn and J. D. Soule).

${ }^{6}$ MacGinitie, G. E. 1955. Distribution and ecology of the marine invertebrates of Point Barrow, Alaska. Smithson. Misc. Coll. 128, (9), 201 pp., Pub. 4221.

${ }^{7}$ Abrikosov, G. G. 1948. Bryozoa. In Gaevskaia-Sokolova, N. S., et al. Opredelitel' fauny i flory severn'ykh morei SSSR. Moskva. pp. 451-61.

8Ushakov, P. V. 1952. Chukotskoe more i ego donnaia fauna. Akad. nauk SSSR. Krainii Severo-vostok Soiuza SSR., 2, pp. 5-82. 